MANN

$\mathrm{F}$

127

.C55

K2.

LIBRARY

ANNEX

2 
Cornell University Library
F 127.C55K2

The finger lakes of central New York.

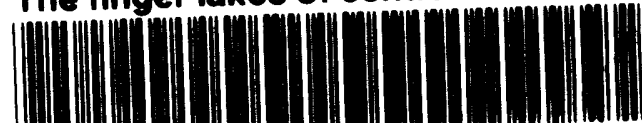

31924014092187

ALBERT RANA LIBRART

邻

CORNELL VNAMERSTIT

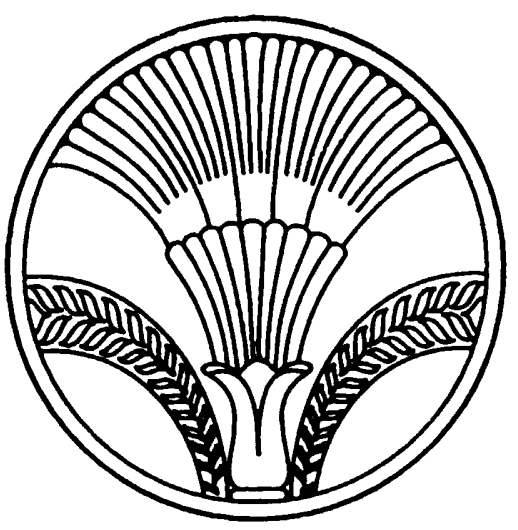




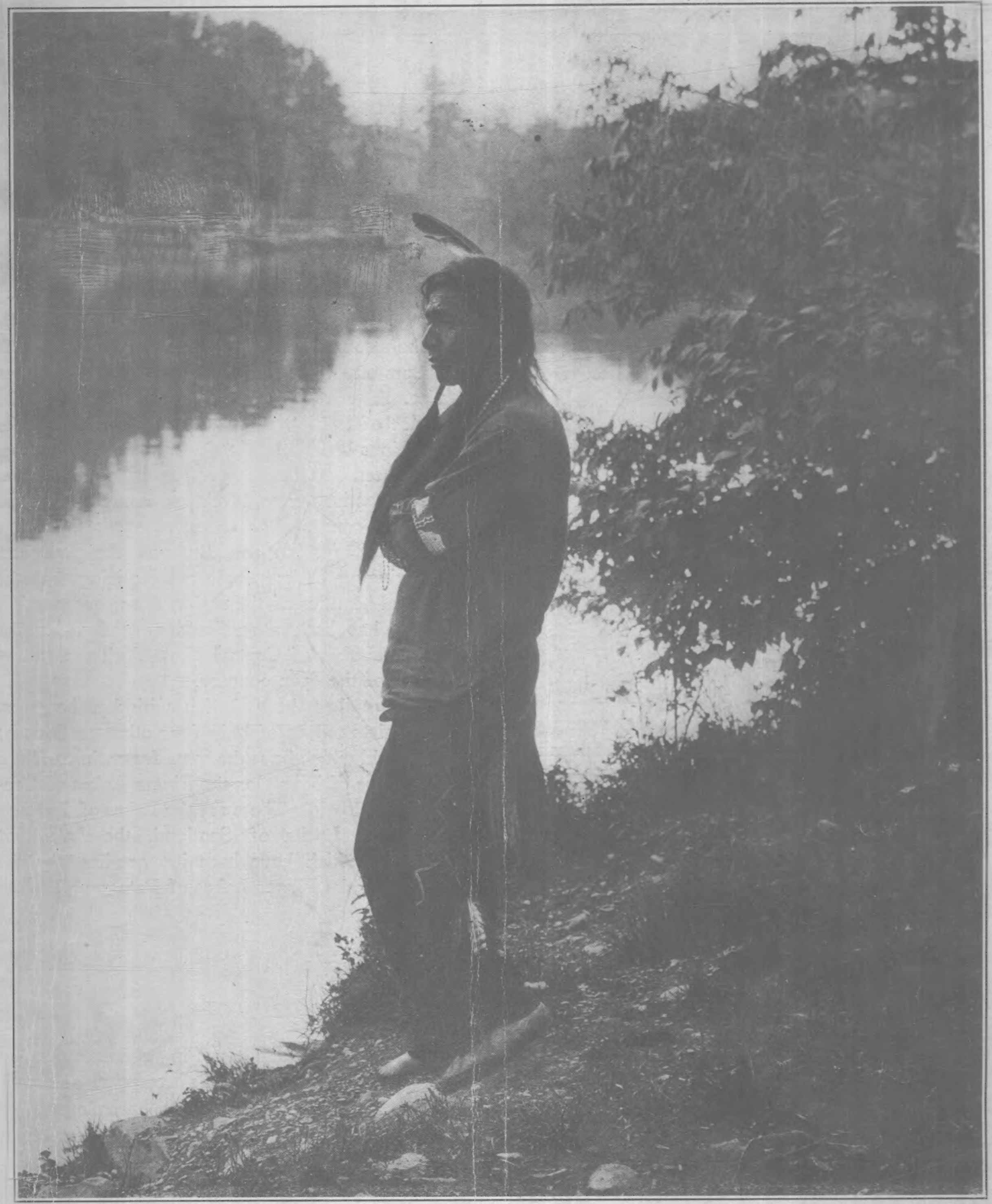

In the Finger Lakes Region Lived the Iroquois 


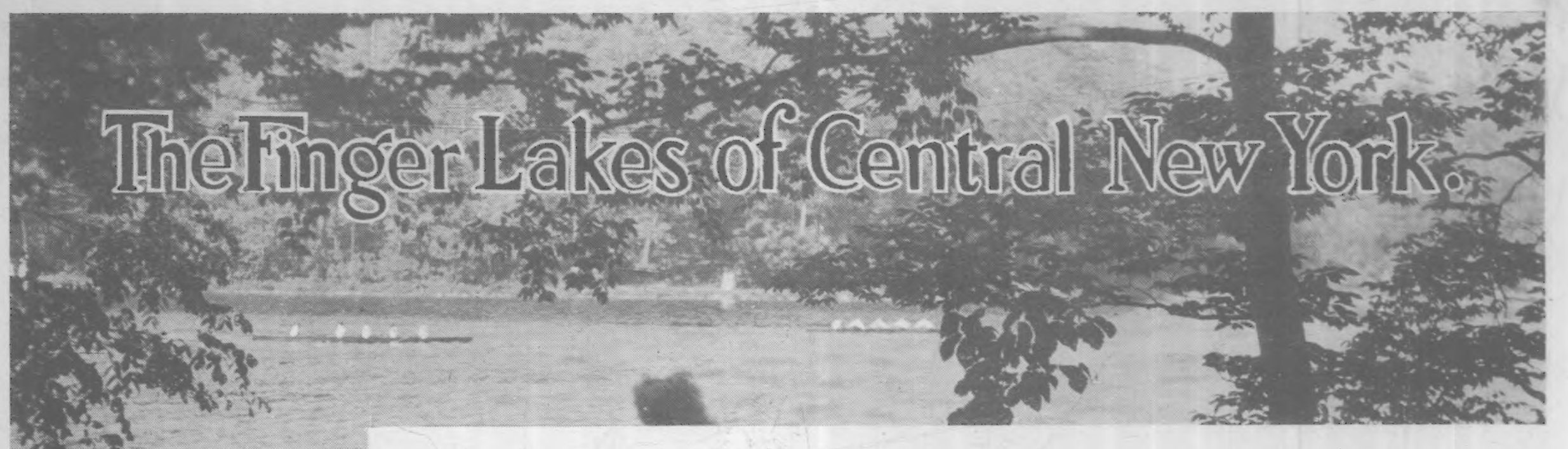

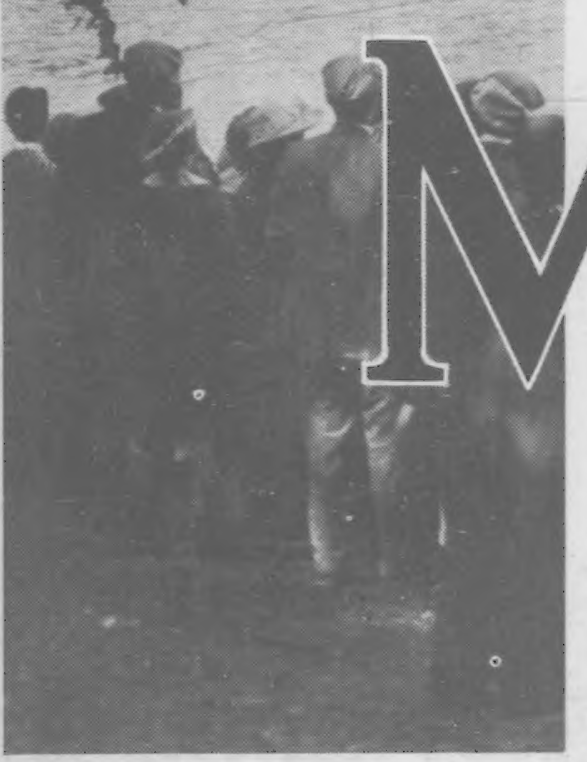

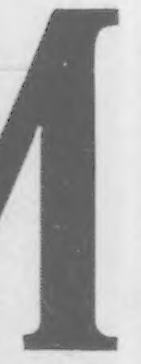

ANY thousand motorists from the Middle West s peed through Central New York each summer bound for the A d ir o n d a cks, the mountains of New England and the At. lantic Coast Resorts. Similarly the New

Yorkers and New Englanders motor to the north and west to find a playground. Pennsylvanians have dashed through the lake country bound for the Adirondacks and the Thousand Islands; many without stopping to admire the beauties on every hand. The Finger Lakes of Central New York - a region which has more glens and gorges than any section of its area east of the Rockies and a waterfall fifty feet higher than Niagara - are at last demanding recognition.

\section{The Beauty Spot}

\section{Man Forgot}

Why has the region been overlooked? The reason is a good one. Before the opening of the Adirondacks and many New England resorts the lakes of Central New York were very popular. The trade was sufficient to warrant the erection

Page two of handsome hotels on the banks of these inland waters and to maintain adequate steamboat service. The coming of the automobile and the desire of tourists to get farther from home for vacations brought about the change. Distant resorts seemed to have greater attraction. Other resort sections were developed commercially and the lake country was forgotten except by a few of its faithful friends. But now the pendulum is swinging back; people are realizing that the natural beauties of the region are unsurpassable. There has been a re-discovery and today the Finger Lakes of Central New York are calling lovers of the open country.

Nature has been lavish with her bounties. Geologists tell us of only four other sections of the world which have the same formation and the same type of beauty as the Finger Lakes of Central New York. These are the Lakes of Switzerland, the Lochs of Scotland, the Lakes of England which have been immortalized by the poets and the Finger Lakes of Patagonia.

\section{Good Roads}

\section{Everywhere}

Good roads make the Finger Lakes Region easily accessible. With the exception of a few short stretches it is possible to encircle each of the six lakes on macadam pavement. Variety is the keynote of the region. One can never tire of the country. It is a land of grand and gloomy gorges with tumbling brooks, crashing cataracts 


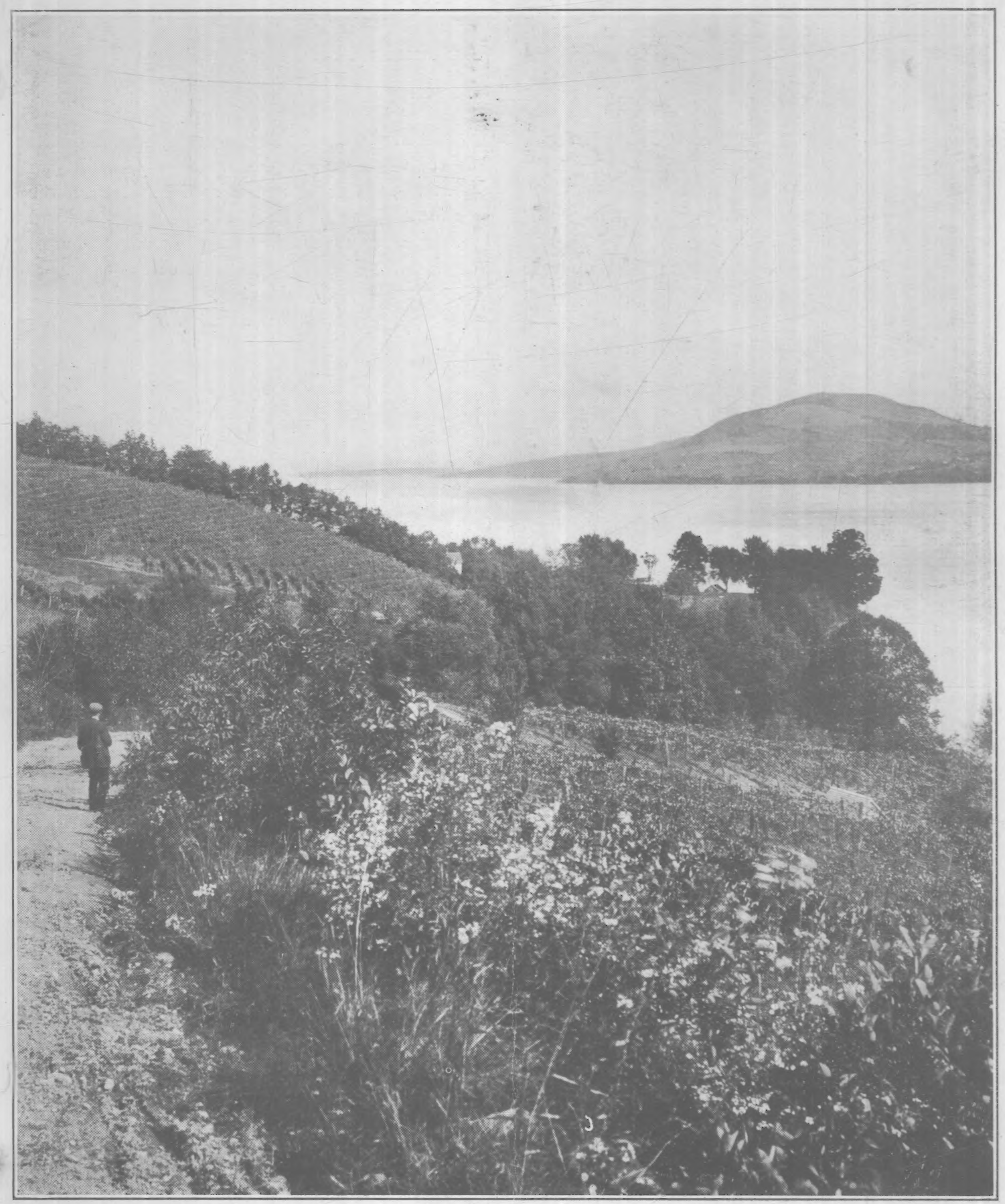

Vineyards--.Canandaigua Lake 


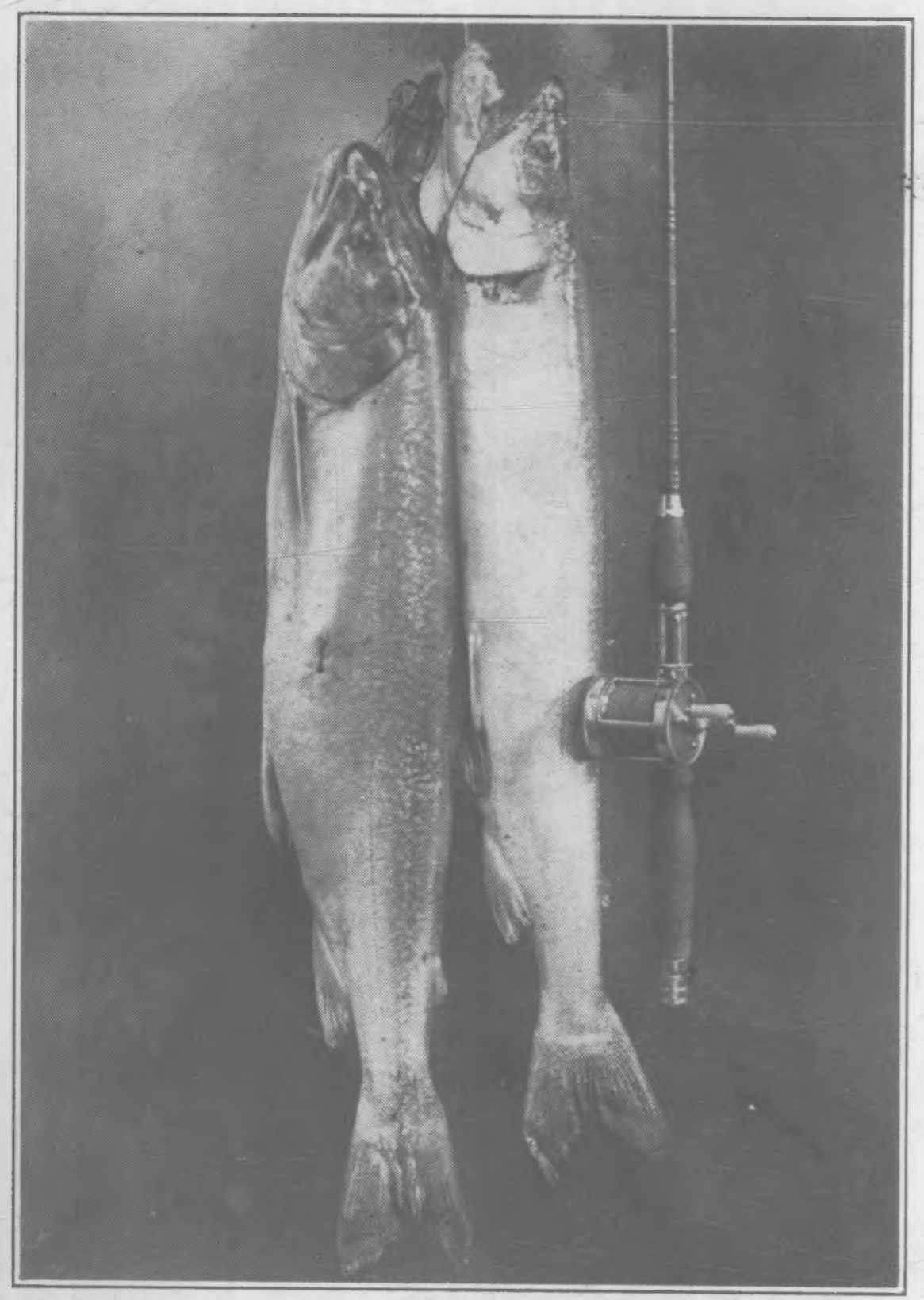

Seneca Lake Beauties

and dancing cascades, with wild ravines, sequestered glen and sylvan dells and the great expanses of the lakes themselves. The works of man in the region are equally pleasing. The land is well cultivated. The farm buildings and general appearance of the fields testify to the prosperity of the country-side. The cities and villages of the region are clean and attractive. There are good hotels and adequate garage accomodations.

The Finger Lakes country is bordered and traversed by railroads. It may be reached by the New York Central, Lehigh Valley, Delaware Lackawanna and Western, and Northern Central and is only a few miles from the E,rie and Delaware and Hudson.

\section{An Enchanted}

\section{Country}

The Finger Lakes Region is the section of the United States where the highest type of Inclian civilization was developed. Long before the white man came, the Iroquois cleared the land and put it under cultivation. They lived in houses. Their form of government was of the representative type-each of the Six Nations having representation in the Great Council of the Confederacy.

In this locality three religions have been bornThe Indian religion of Chief Handsome Lake, Mormonism and Spritualism. The student of history may spend months in the Finger Lakes country without exhausting its possibilities.

\section{The Five}

\section{Gateways}

The main auto routes are the northern and southern boundaries of the Finger Lakes Region. The main gateways are at Canandaigua and Skaneateles on the northern routes and at Ithaca, Montour Falls, and Hammondsport on branch roads from the southern route. The lake region-is 250 miles from New York City, I65 miles from Albany and 85 miles from Buffalo.

The region contains 2,000 square miles. The six largest lakes appear on the map very mucin as a hand with the fingers extended downward. From west to east the lakes are as follows:. Canandaigua, Keuka, Seneca, Cayuga, Owasco, and Skaneateles. The headwaters of the streams feeding these lakes are in the height of land dividing the Great Lakes watershed from the watersheds of the Atlantic Ocean and the Gulf of Mexico.

\section{Canandaigua Lake}

Canandaigua Lake was known as the westerı door of the region in the days of the Iroquois. The Senecas, the greatest warriors of the confed- 


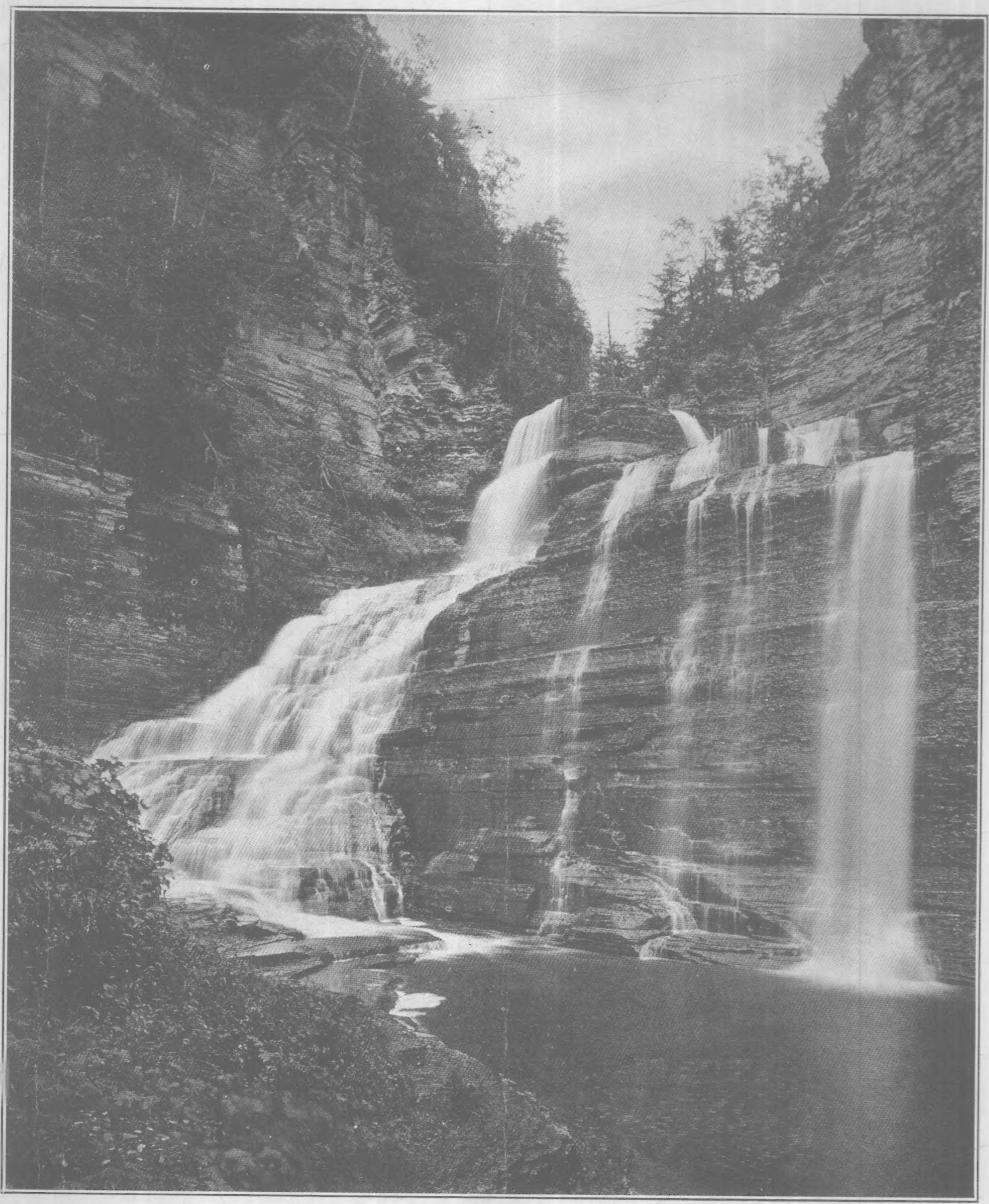

Enfield Falls 


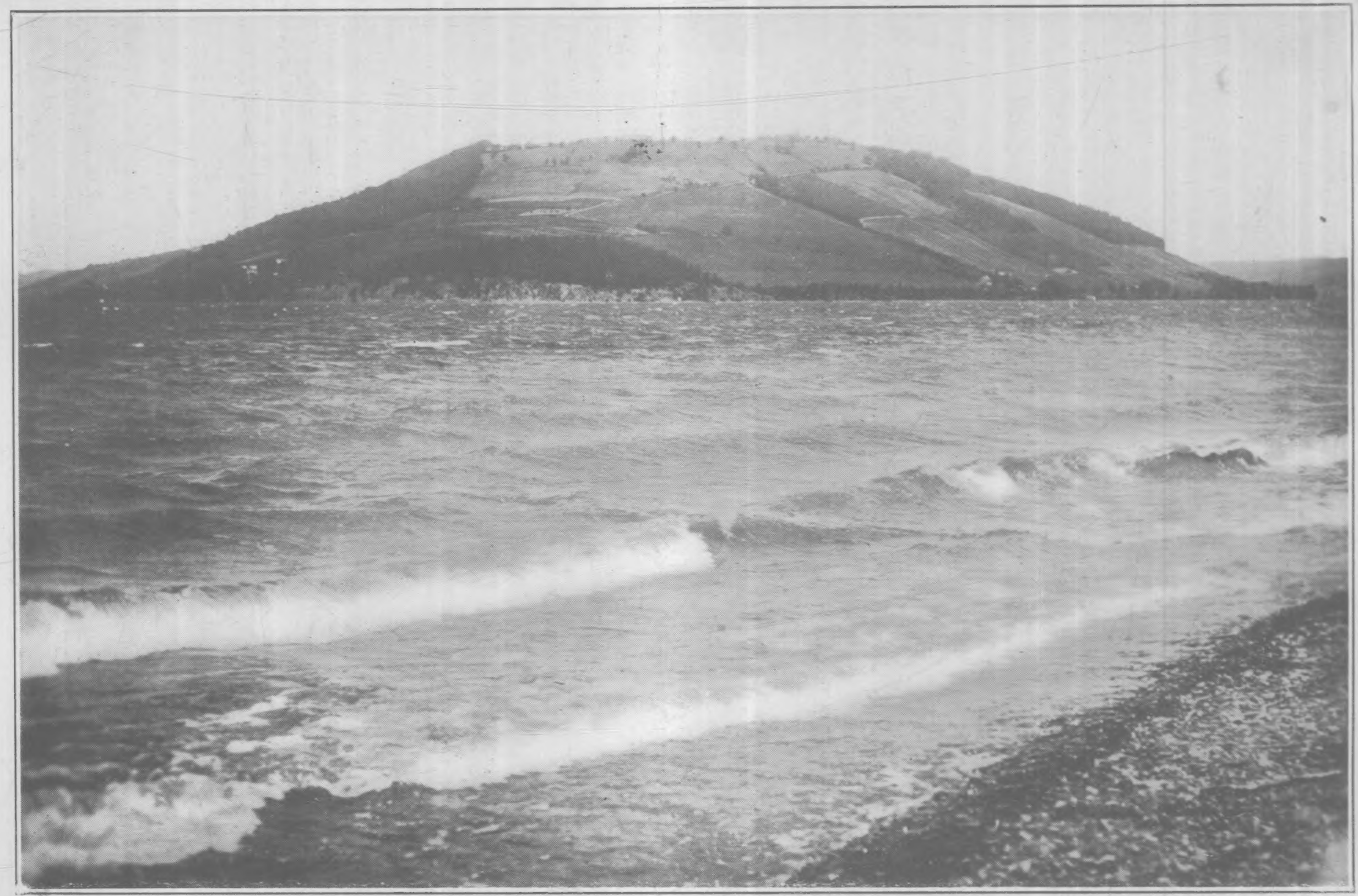

Bluff Point---Lake Keuka

eracy were the "Guardians of the Western Door." They lived in the vicinity of Canandaigua Lake. Although the territory of these invincible warriors extended from Lake Ontario to the Alleghanies, and from Seneca Lake to the Niagara River, the official center of their domain, the seat of their government was at Canandiagua. Lake. The very name Can-an-dar-que or Kanan-da-que as it is sometimes spelled signifies "The Chosen Spot."

It was at Canandiagua in 1789 that the first office for the sale of land was opened. Canandaigua is a village worthy of careful inspection by the tourist. Seldom does one find such wide streets and expanses of well kept lawn, such splendid shade trees and such stately old mansion houses.

Pagesix

\section{Lake Keuka}

Keuka or Crooked Lake appears on the map as a Y leaning to the east to meet its neighbor Seneca. The lake is the wildest of the group. The hills which surround it dip into its emerald depths without the beach line usual to most of the Finger Lakes. Only where creeks which tumble from the hillsides have brought down deposits are there beaches of any size.

Bluff Point which divides the east from the west branch of Lake Keuka is the most outstanding feature of its topography. From this lofty promontory on a clear day seven countie and a dozen lakes are in view.

\section{Wines and Aeroplanes}

Lake Keuka is in the heart of the vineyard 


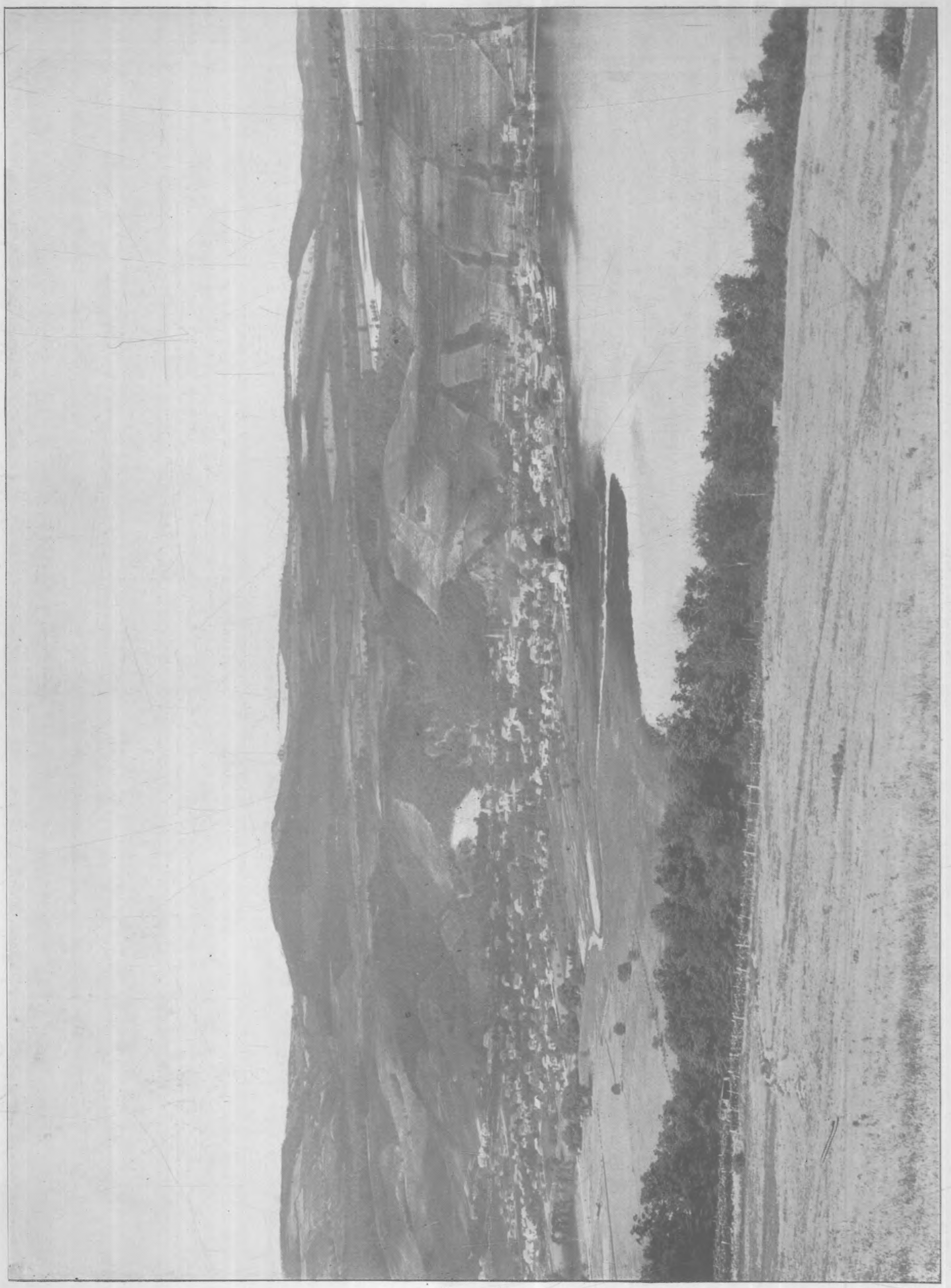

सै

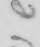




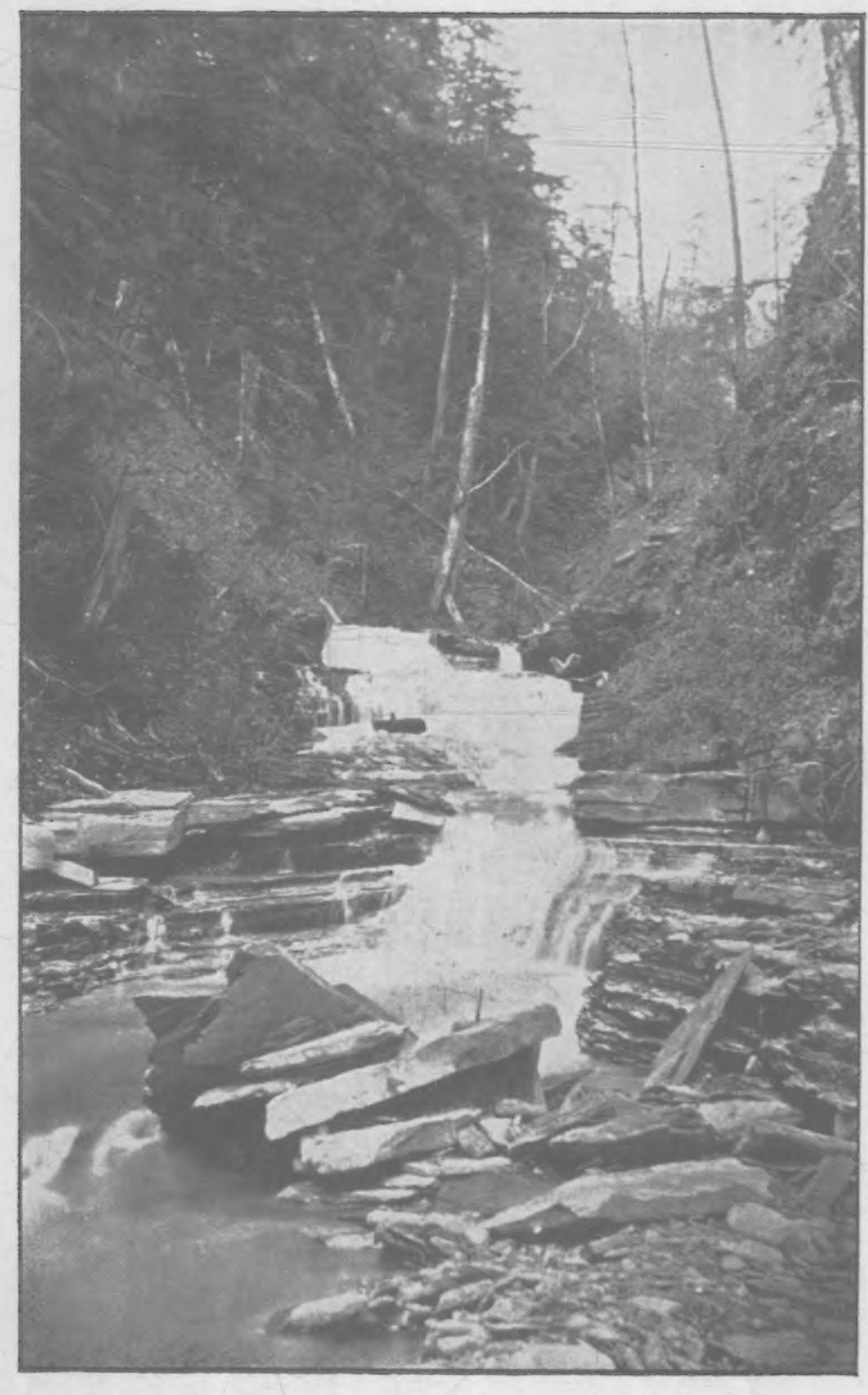

In Montour Glen
Four of the American naval aviators who started across the ocean in the famous NC's learned to fly over Lake Keuka.

\section{Penn Yan, Queerest of Names}

Penn Yan, located at the outlet of Lake Keuka has one of the queerest names to be found on the map of New York State. The early settlers were Pennsylvanians and Yankees. The name PennYan is the result.

Montour Falls three miles from the head of Seneca Lake is a village rich in historical associations. Three picturesque and romantic glens as well as several smaller ravines, are worthy of visitation and exploration. The Council Chamber in Montour Glen is a truly wonderful natural phenomenon. It is about one hundred feet in length, and twenty-five feet in breadth for more than two-thirds of the distance. The high walls at three sides of the chamber are as square as if hewn by man. The Council Chamber has no counterpart in the Finger Lakes Region.

\section{Catherine Montour}

Catherinestown was the original name of the village. It was named for Catherine Montour, the renowned chieftess of the Seneca tribe of Iroquois whose nod was law and who was an oracle of her people. This remarkable woman,

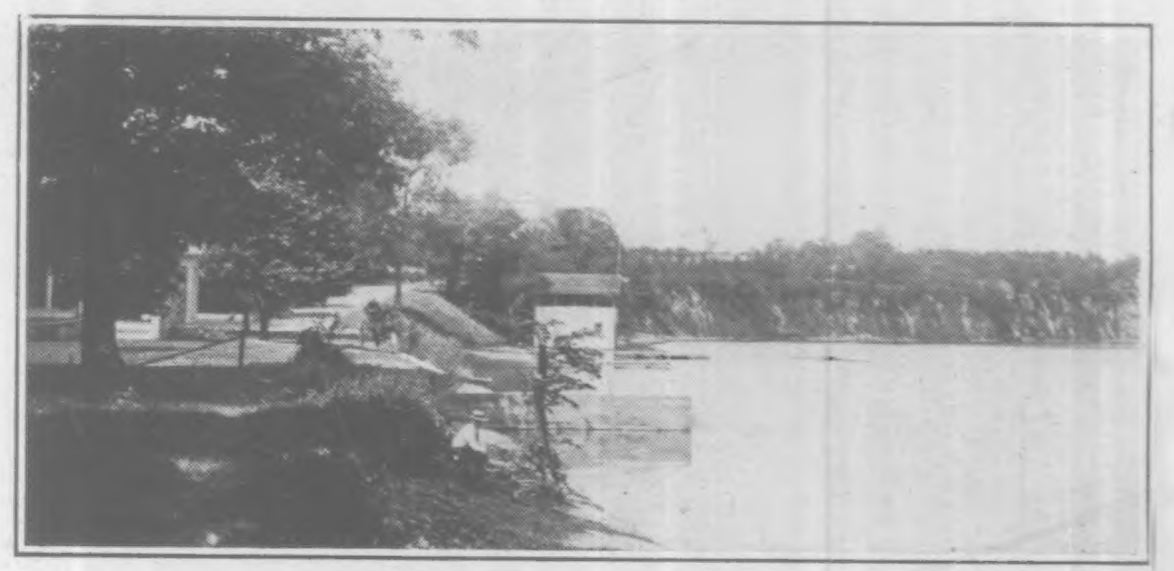

Sheldrake Point-.-Cayuga Lake 


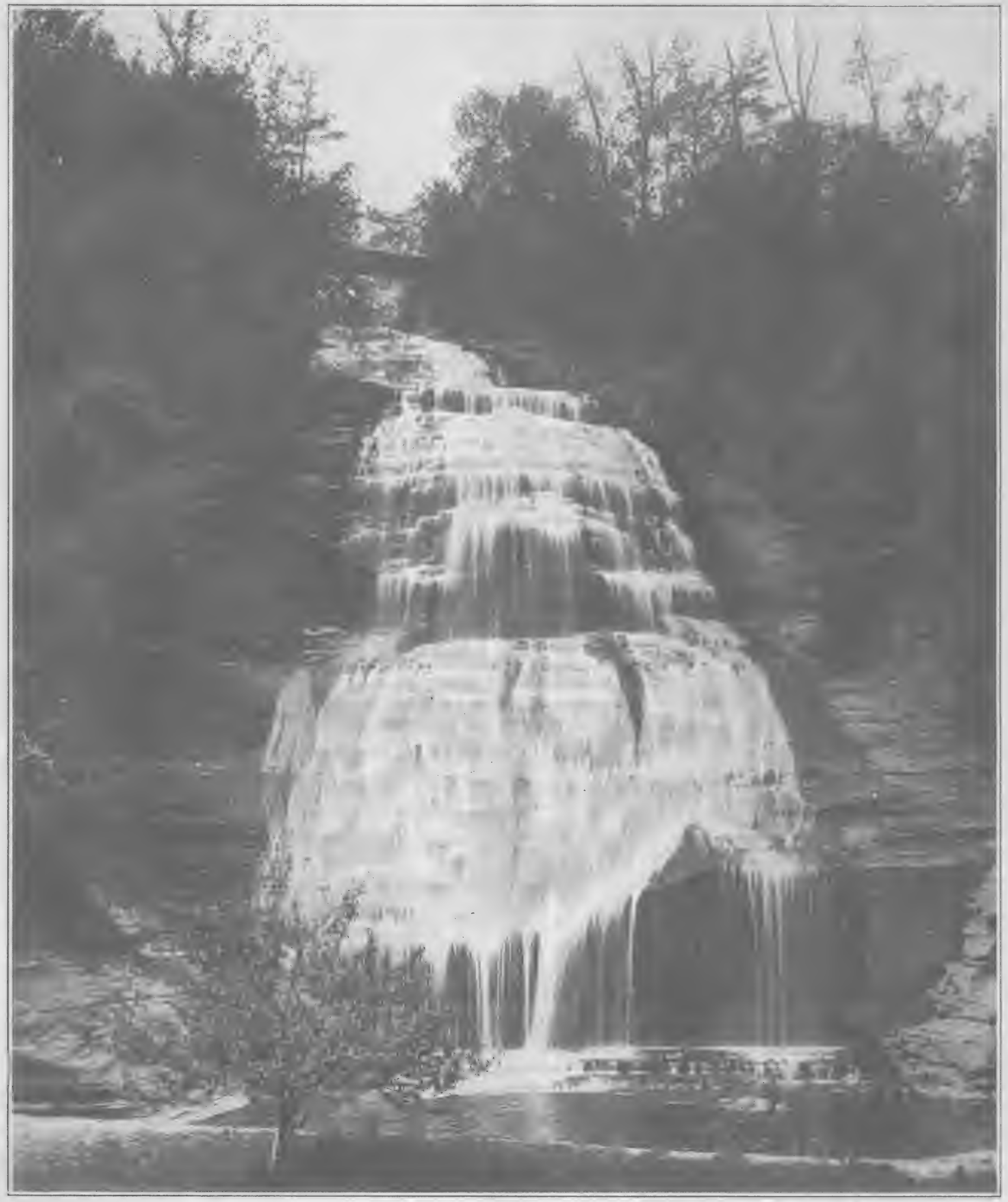




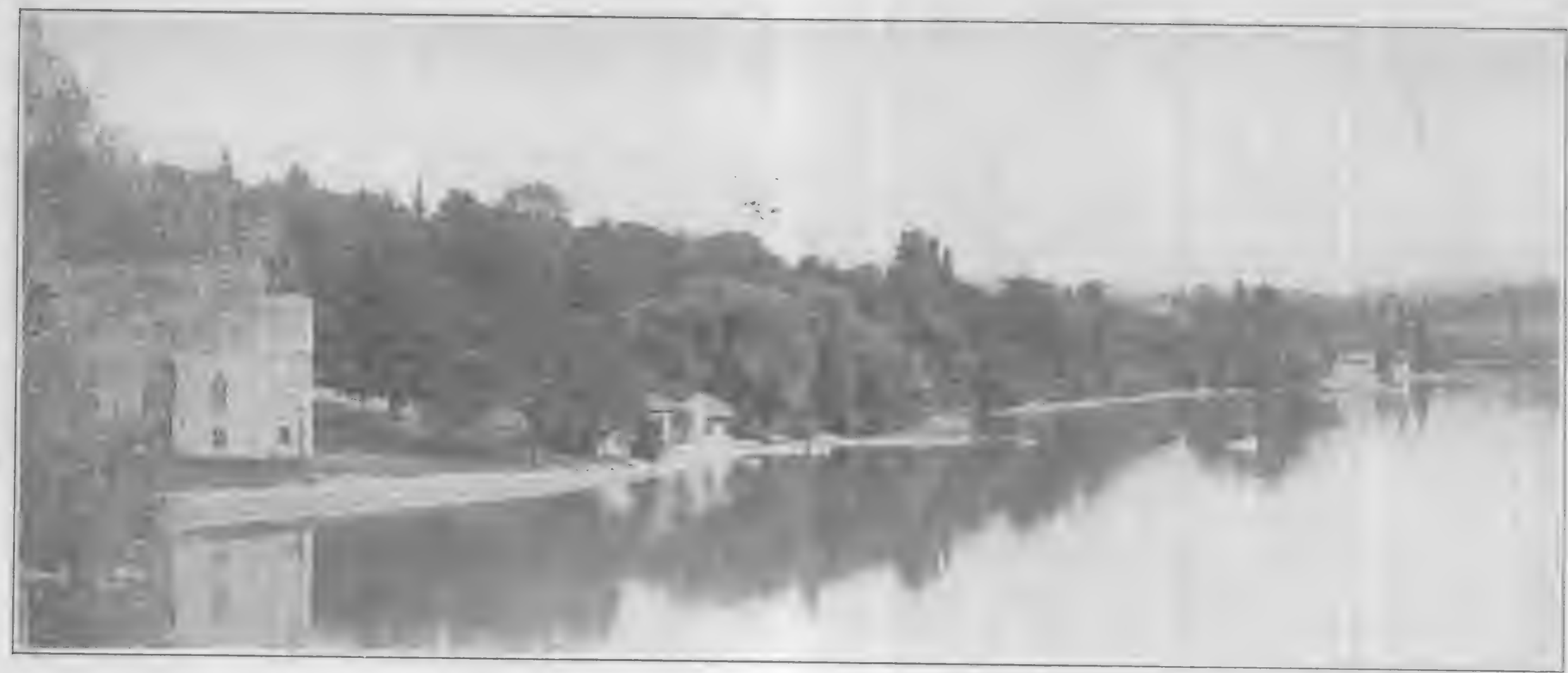

Along the Shore---Skaneateles Lake

half French and half Indian, was taken into the Seneca tribe as a prisoner of war. She won the heart of the great chief of the Senecas, Montour, and became his wife. She was known as Queer Catherine. Her village of Catherinestown was wiped out by General Sullivan's expedition in 1779. When settled by white men Montour Fails was first called Havana. The name was changea quite recently to the present title.

Much of the early growth of Montour Falls was due to Charles Cook who founded the "Peoples College," still operating under the name of Cook Accademy. The principal industry of the village now is the manufacture of electric hoists.

\section{Seneca Lake}

Seneca Lake is the body of water irom which the trout shown on page four were taken. It lays claim to being the deepest body of water entireiy within the boundaries of the United States. The Seneca Lake or Salmon trout for which the lake is noted are a strictly game fish. They vary in weight from 3 to 30 pounds. Fine soft drawn copper wire is used for a line. Trolling is the method used most successfully.

Geneva at the head of Seneca Lake is a city of Page ten
I5,000 population. Hobart College, Villianli Smith College for Girls and the Genera Classicai School for boys are located here. The city has a large frontage on the lake. A beautiful lakeside park has been built by the city. Many of the beautiful residences of the city have lawn: running down to the water's edge.

The section of the Finger Lakes Region adjacent to Geneva is rich in Indian lore. Many relics are found near the head of Seneca Lake. Indian forts have been unearthed and near ine city a defensive structure known as Gan-un-dasa-ga Castle may be seen. This fort was destrored by General Sullivan's expedition in I579.

Geneva is a center for the imanufacture of cutlery and optical goods. Gasoline engines, stoves and heating equipment are also manufactured in the city. Many large nurseries are located near the city.

\section{The Land of}

\section{the Senecas}

Although the whole lake region abounds in historic interest and Indian lore, the section about Seneca Lake is of particular interest. When General Sullivan's expedition marched through 


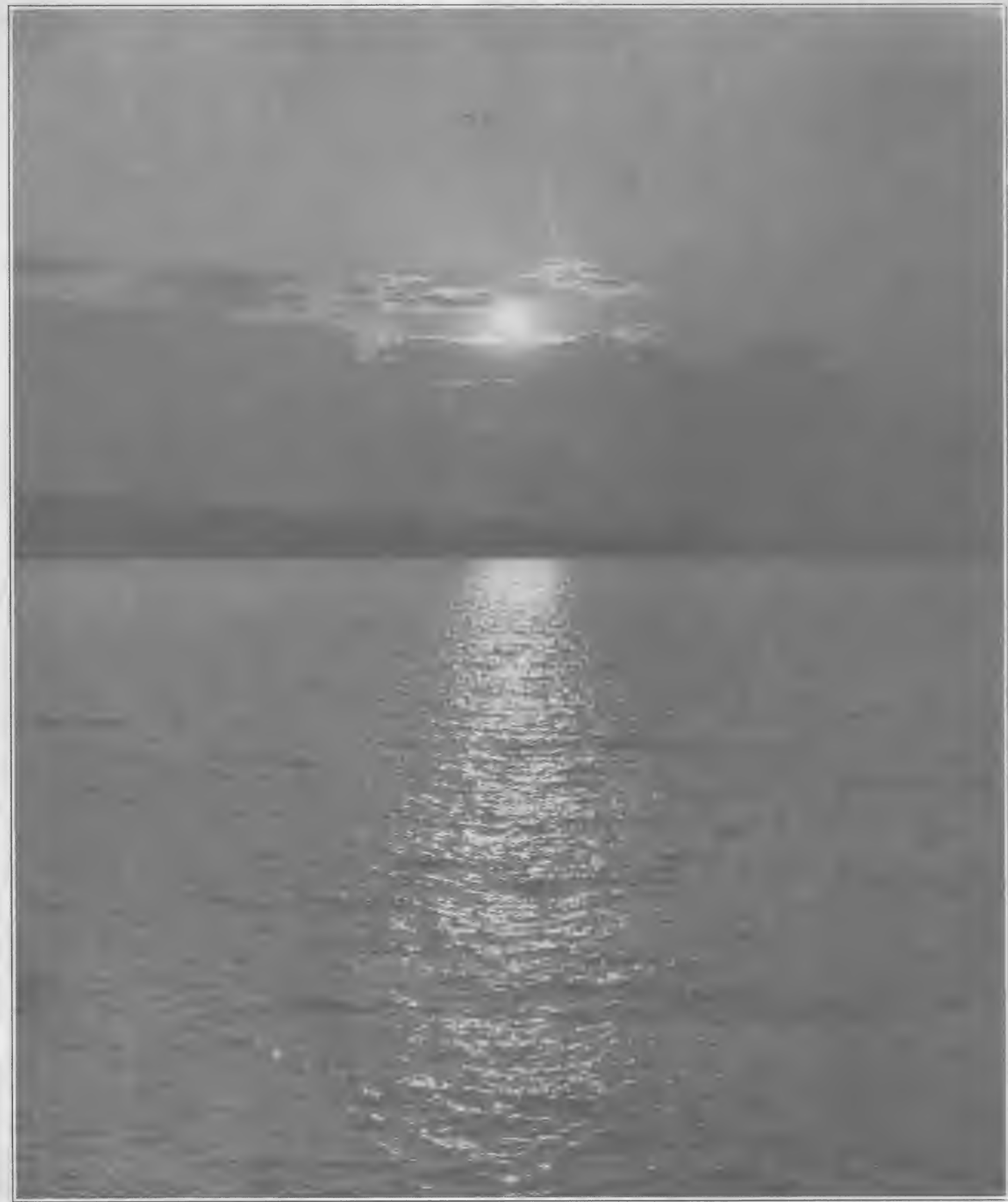




\section{The $\mathrm{B}^{\circ}$}
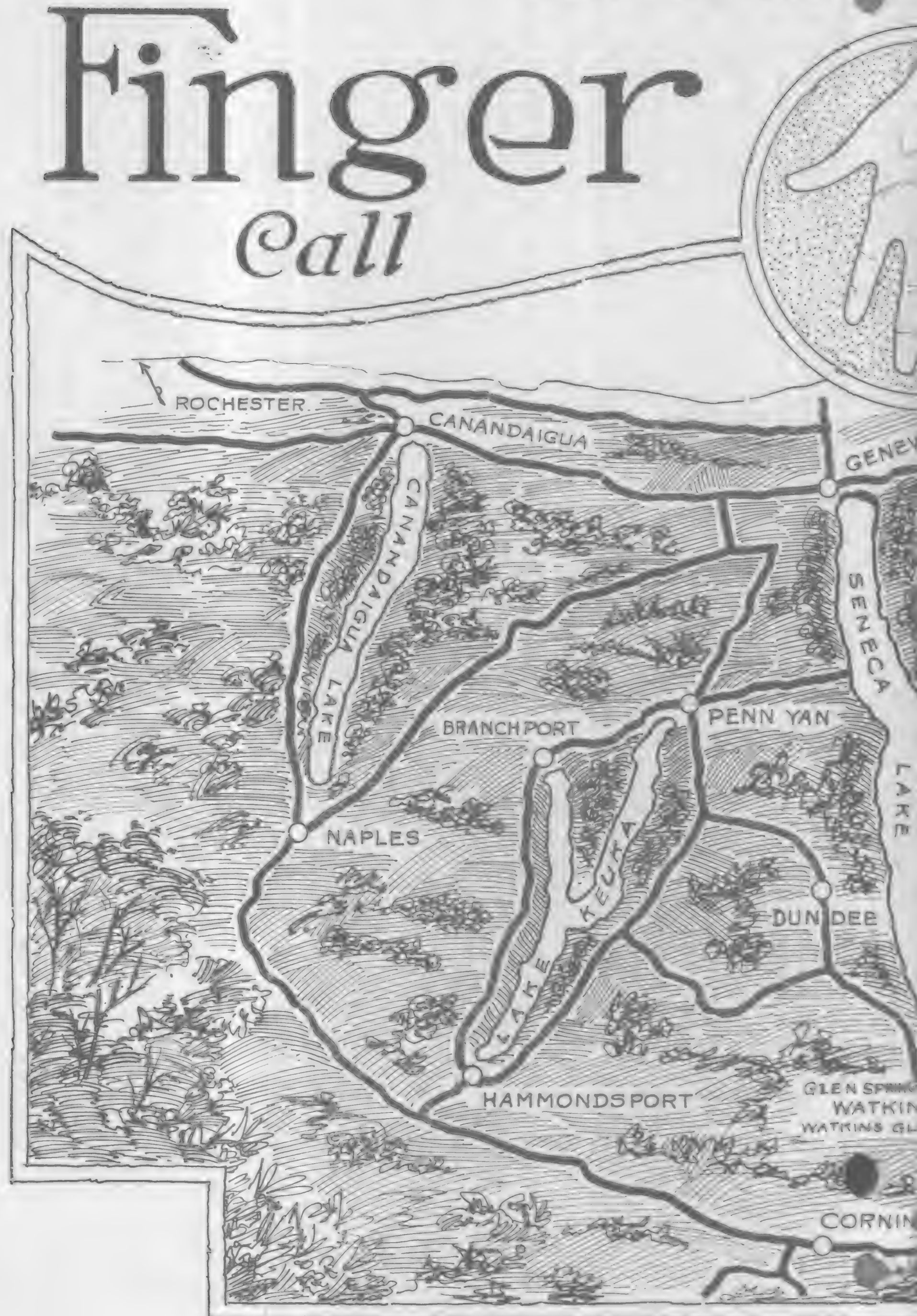


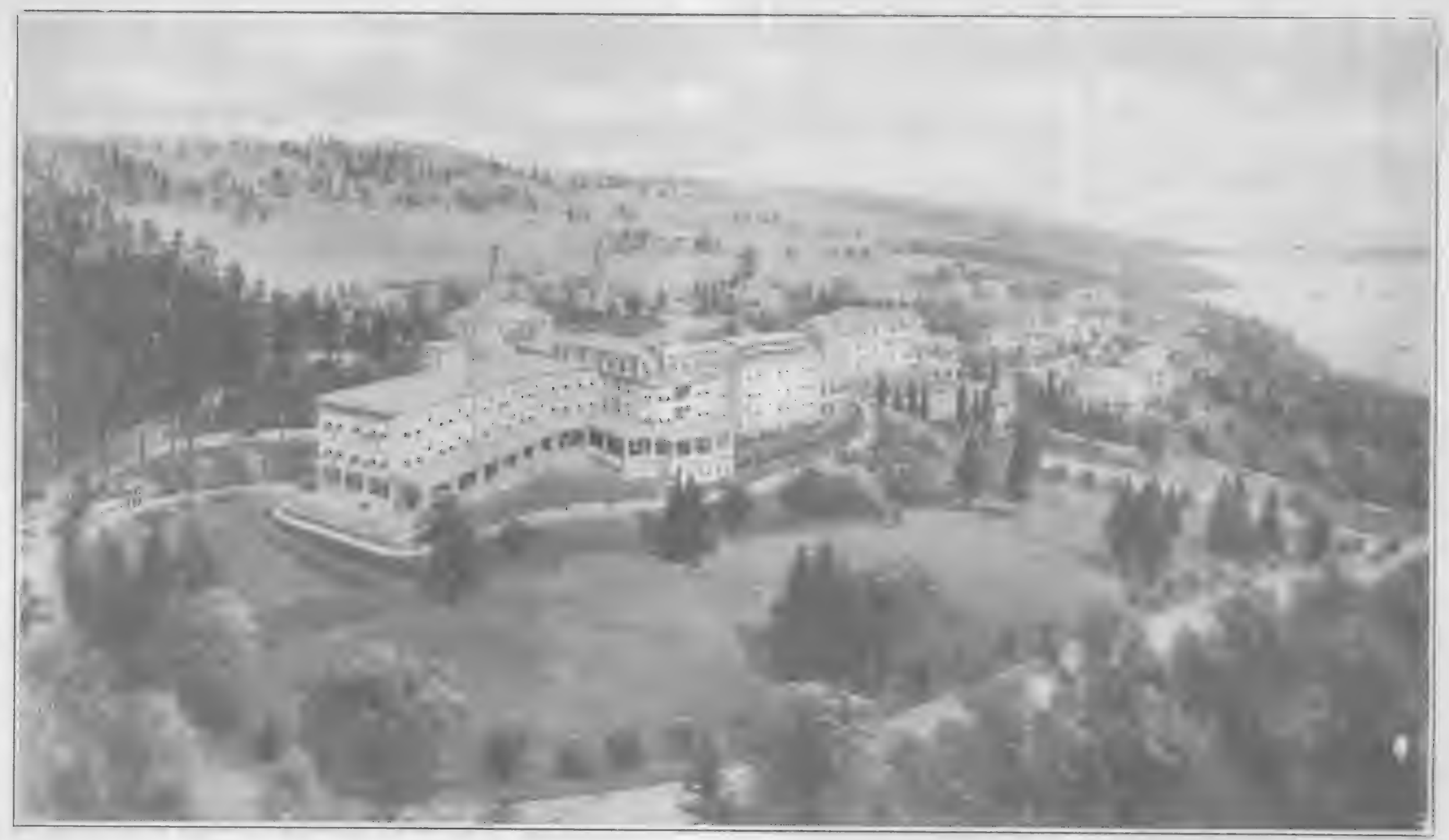

Glen Springs---Seneca Lake

the country in I779 on its mission of vengeance for the Cherry Valley and Wyoming massacres, the soldiers found orchards and cultivated field's. It was the duty of Sullivan's army to destroy the Indian towns, cut down the orchards and burn the grain, for the red warriors were a great menace to the Continental Army.

Many evidences of Indian occupation are-still to be found in the vicinity of Seneca Lake. A short distance from the head of the lake are Painted Rocks, covered with Indian inscriptions and rising sheer from the water for over a huindred feet.

\section{Seneca Lake \\ Climatology}

A remarkable feature of Seneca Lake is that it has frozen over only twice in a century. At at depth of 200 feet it maintains a uniform temperature of 7 degrees above freezing throughout the Page fourteen year. 'The temperature of the water is so low that evaporation is very slight, rendering the air unusually free from humidity, which accounts for the absence of fogs, the clear skies and the coolness and freshness of the surrounding atmosphere during the summer. United States IVeather Bureau records extending over a period of more than twenty years give the mean temperature for midwinter as 23 degrees and for midsummer as 69.8 degrees.

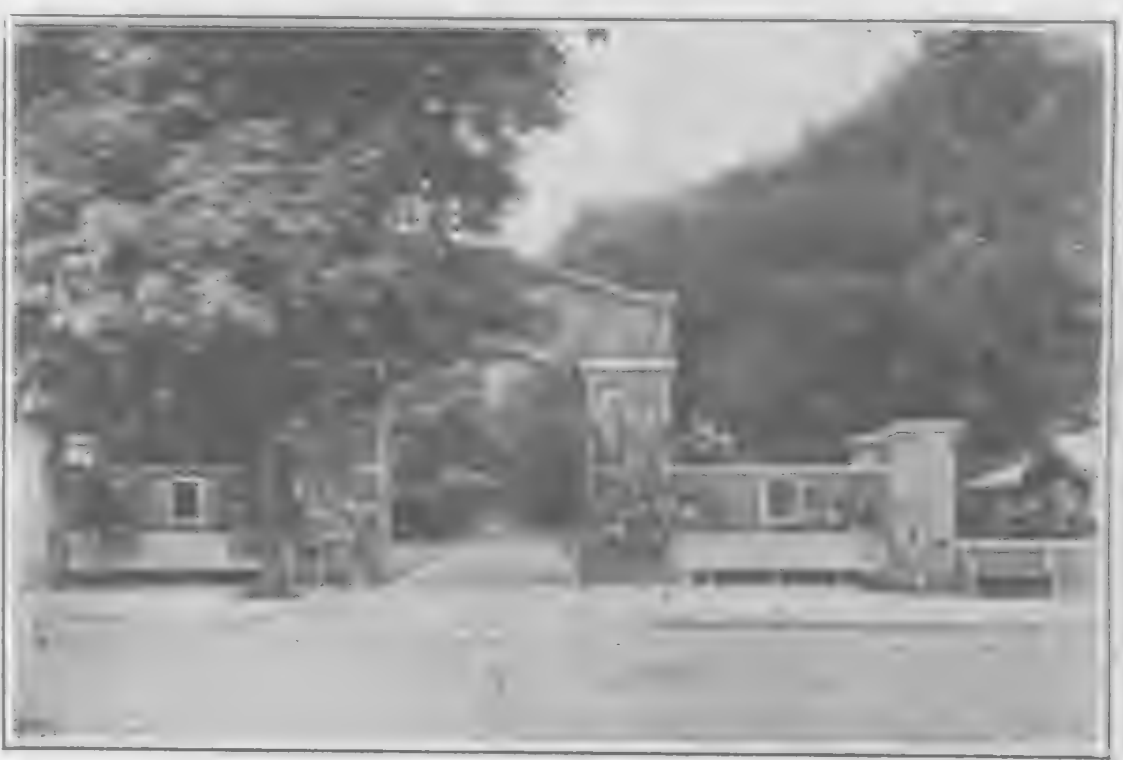




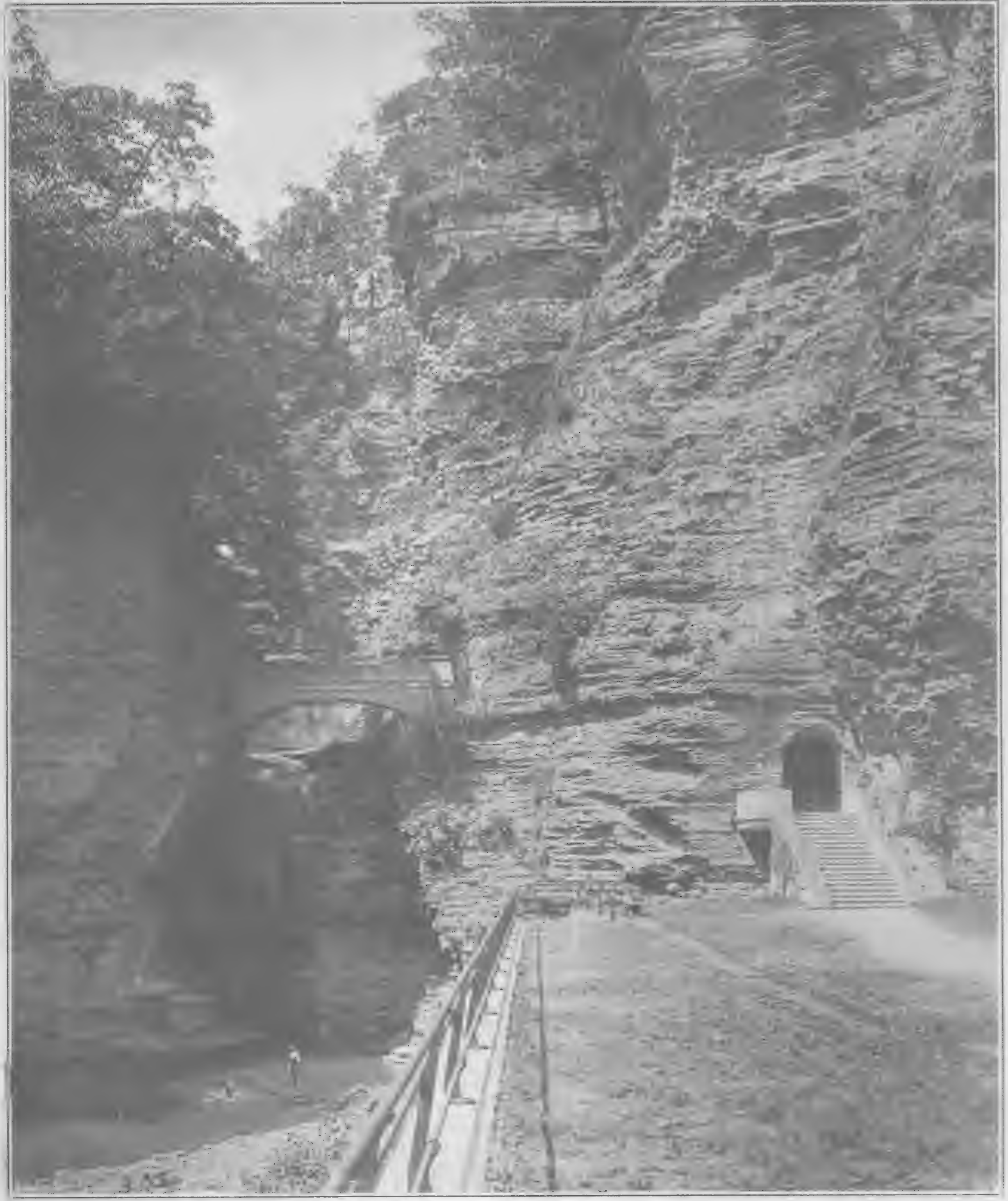




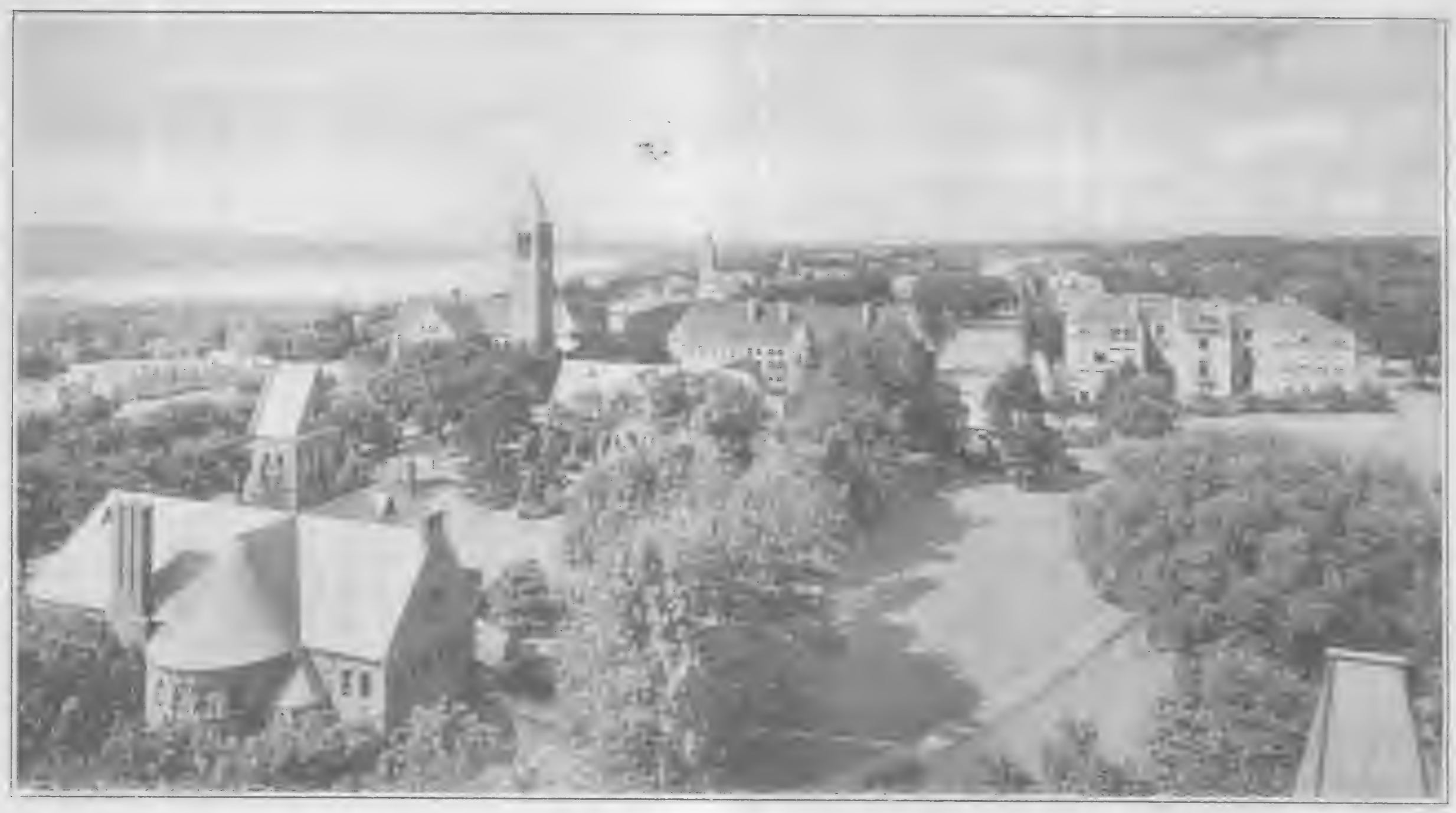

Cornell Campus and Cayuga Lakc

\section{A Warning}

\section{To Visitors}

Seneca and Cayuga Lakes have acquired the unenviable reputation of exacting their toll of human lives each year from those who sail, row or paddle on their waters. The lakes need have no terrors for those who will use ordinary common sense. It is -tunwise for anyone who cannot swim to venture far from shore in a canoe or small row boat, for occasionally storms come up unexpectedly. In mid-lake the water, because of its great depth, is cold almost the year round. Even experienced swimmers are liable to cramps if they remain in the water for a great length of time. It is wise for visitors who venture on the lakes to secure the services of an experienced boatman. When this is done the joys of canoeing, yachting and motorboating may be enjoyed without fear of mishap.

\section{Sports of the}

\section{Lake Region}

The motorist who intends to spend his vacation in the Finger Lakes Region is advised to bring his golf clubs if he is fond of the links. There are numerous country clubs throughout the region and some of the hotels have courses for the use of guests. The rolling hillsides of the lake country make hazards which will arouse the enthusiasm of all lovers of the sport.

The visitors to the lake country who do not come by motor may secure carriages, automobiles, motor boats, yachts, row boats or canoes by the day or hour at almost any of the cities and villages located on the lakes. Good trout and bass fishing are found in the lakes of the region and late in the fall duck shooting is a popular sport. Quail, partridge, pheasant, squirrel and other small game furnish plenty of diversion for the hunter. 


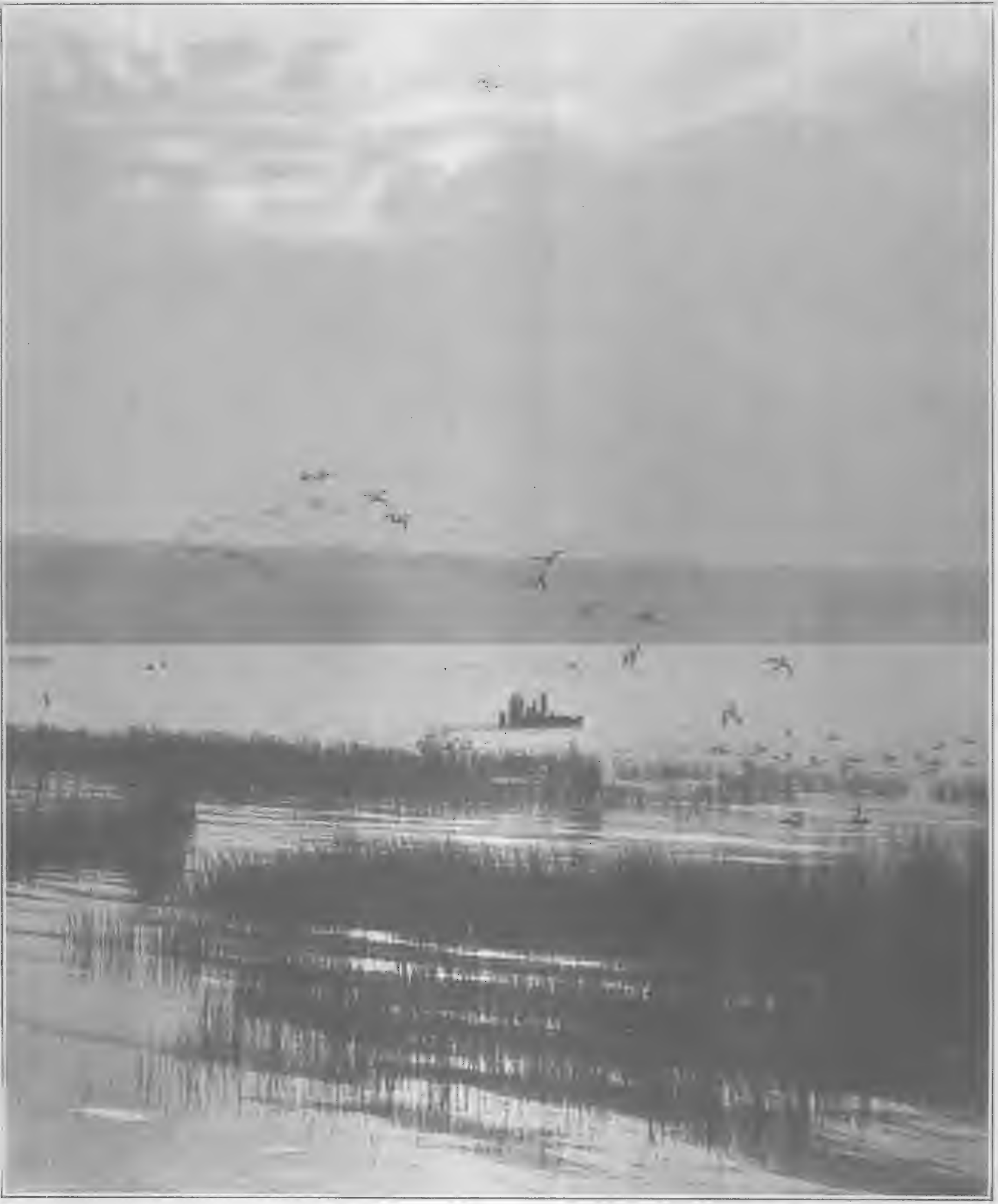

The Ducks Are Flying -..Cayuga Lake 


\section{Watkins Glen}

Watkins Glen needs no introduction to Americans. 'This famous gorge opens directly: on the main street of the village of Watkins. it few years ago Watkins Glen was taken over by the State of New Iork and made a state park. It is visited annually by thousands of tourists.

Watkins Glen stretches into the hillside for: two and one-half miles. Concrete walks and steps built by the state make it possible to explore the beautiful gorge.

Like its sister city, Ithaca, Watkins is the center of improved highways which radiate into the beautiful lake country. Watkins is within a few miles of Lamoka, Kayutah and Wauneta Lakes, three little patches of silver on the map of the region.

\section{Mineral Water}

\section{Springs}

Although mineral water springs of more or less importance are found throughout the lake country, Watkins has the distinction of being the only place where the healing properties of the waters have been used on a large scale in the treatment of disease

The Glen Springs, a mineral springs health resort and hotel, is more than a commercial organization; it is a national institution. Americans may obtain in Watkins all the medicinal and natural advantages of the European Spas.

Long before the white man came into the lake country the Indians knew of the value of the springs at the head of Seneca Lake, It was a custom for the Seneca Indians to visit the locality to partake of the health giving waters. So, deep rooted was the habit that even within the last quarter of the nineteenth century descendants of the Senecas who once held the land came to Watkins for the purpose. The most celebrated of the springs at Watkins is Deer Lick: Other springs are Nauheim, GIen Kissingen, Salubria and Senega.

Page eighteen
Watkins is located over one of the most profitable salt veins in the United States. Thousands of tons of salt are refined annually from the brine pumped from the earth.

\section{Cayuga Lake}

Cayuga Lake with Ithaca at its head and Seneca Falls near its foot has the distinction of being the largest of the six lakes in the group. Itnaca is a city of $\mathrm{x} \%, 000$ population and 5,000 students during the time when Cornell University and various preparatory schools are in session. The city is cut by three deep gorges formed by Fall Cireek, Cascadilla Creek and Six Mile Creek. There are many beautiful waterfalls within the city limits. To the person who likes to travel afoot Ithaca affords limitless opportunity. The ravines and gorges have been made accessible.

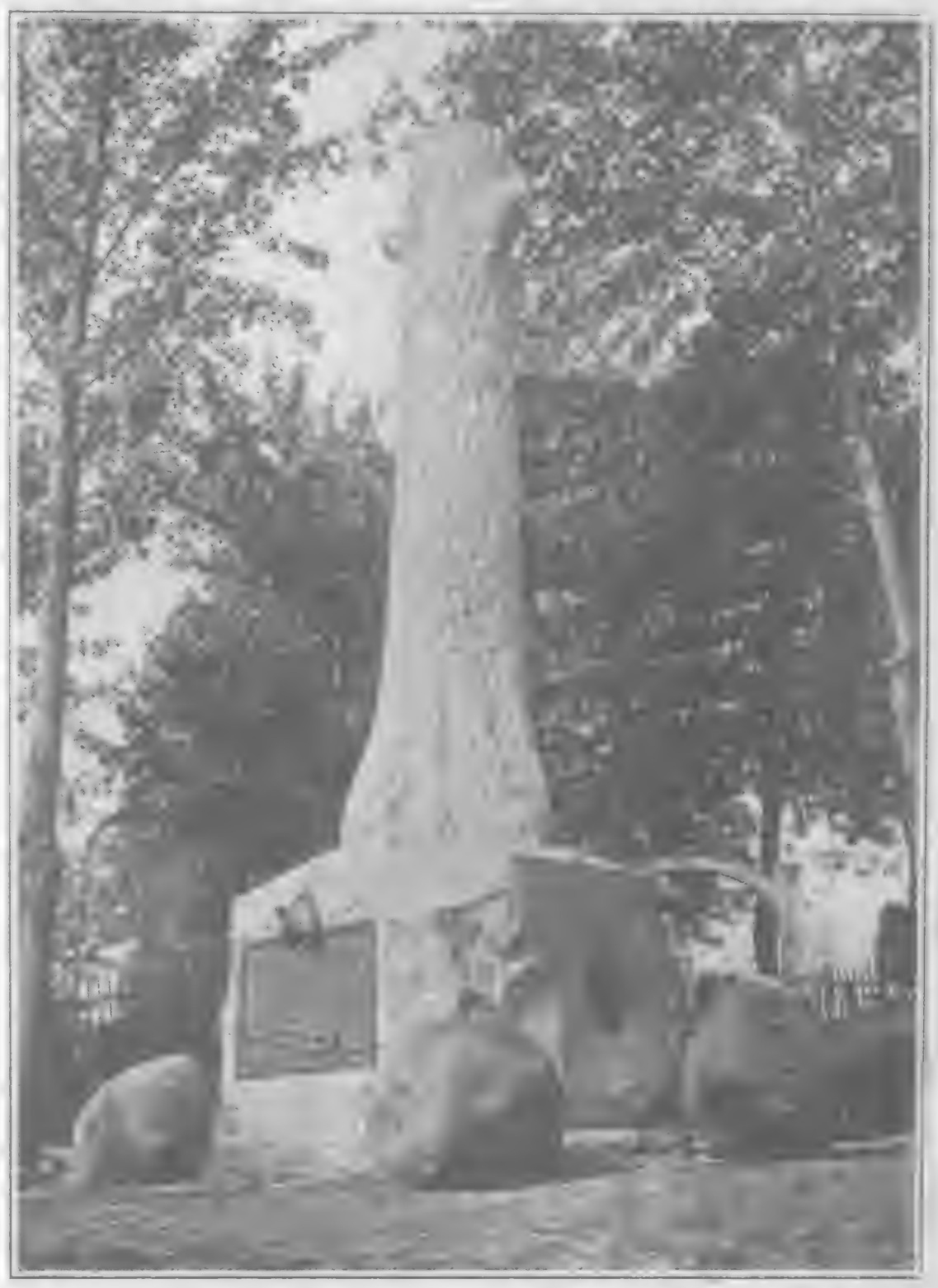

Red Jacket Monument---Canoga 


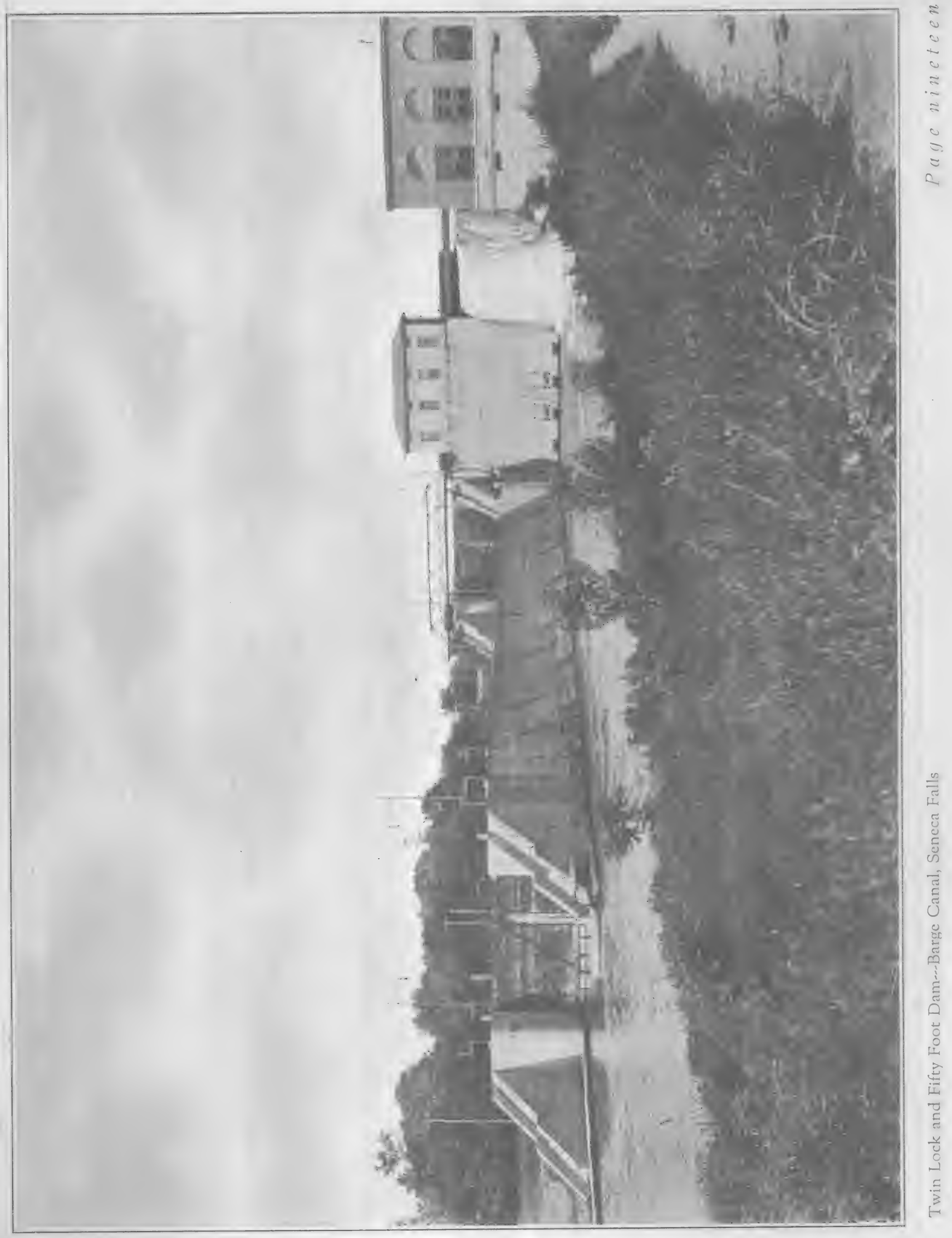


for the nature lover. Taughannock Falls, Buttermilk Falls and Enfield Glen are within a fell miles of Ithaca. Industrially Ithaca is growing. Salt, cement, guns, chain drives, signs, areoplane 5 . and moving pictures are its principal products:

\section{Cornell University}

The university founded in I868 by Ezra Cornell celebrated its semi-centennial in June, Igrg. The half-century of progress which the institution has made is indeed remarkable. The campus now covers nearly I,500 acres in the easterr part of the city and town of Ithaca. There are 35 main buildings and equipment valued at more than $\$ 8,500,000$. The University has an endowment in excess of $\$ 15,000,000$.

The New York State College of Agriculture is a part of Cornell University. This institution is a university in itself if one is to judge from its size. Cornell University has much to interest the tourist. Museums are located in Goldwin Smith and McGraw halls. The University Library has collections of rare books well worth inspection. 'The shops and laboratories of the various colleges are of interest.

\section{Trumansburg and}

\section{Interlaken}

Between Seneca and Cayuga Lakes on the high plateau are two prosperous villages-T'rumansburg and Interlaken. Both are on the main automobile route from Ithaca to Geneva. 'Trumansburg is only a few miles from Taughannock Falls, the highest single falls east of the Rockies. 'Taughannock is shown on the back cover of this booklet.

Interlaken as the name denotes is about miciway between two lakes-Seneca and Cayuga. Splendid views of the lake are to be obtained by driving about in the vicinity of Interlaken. The

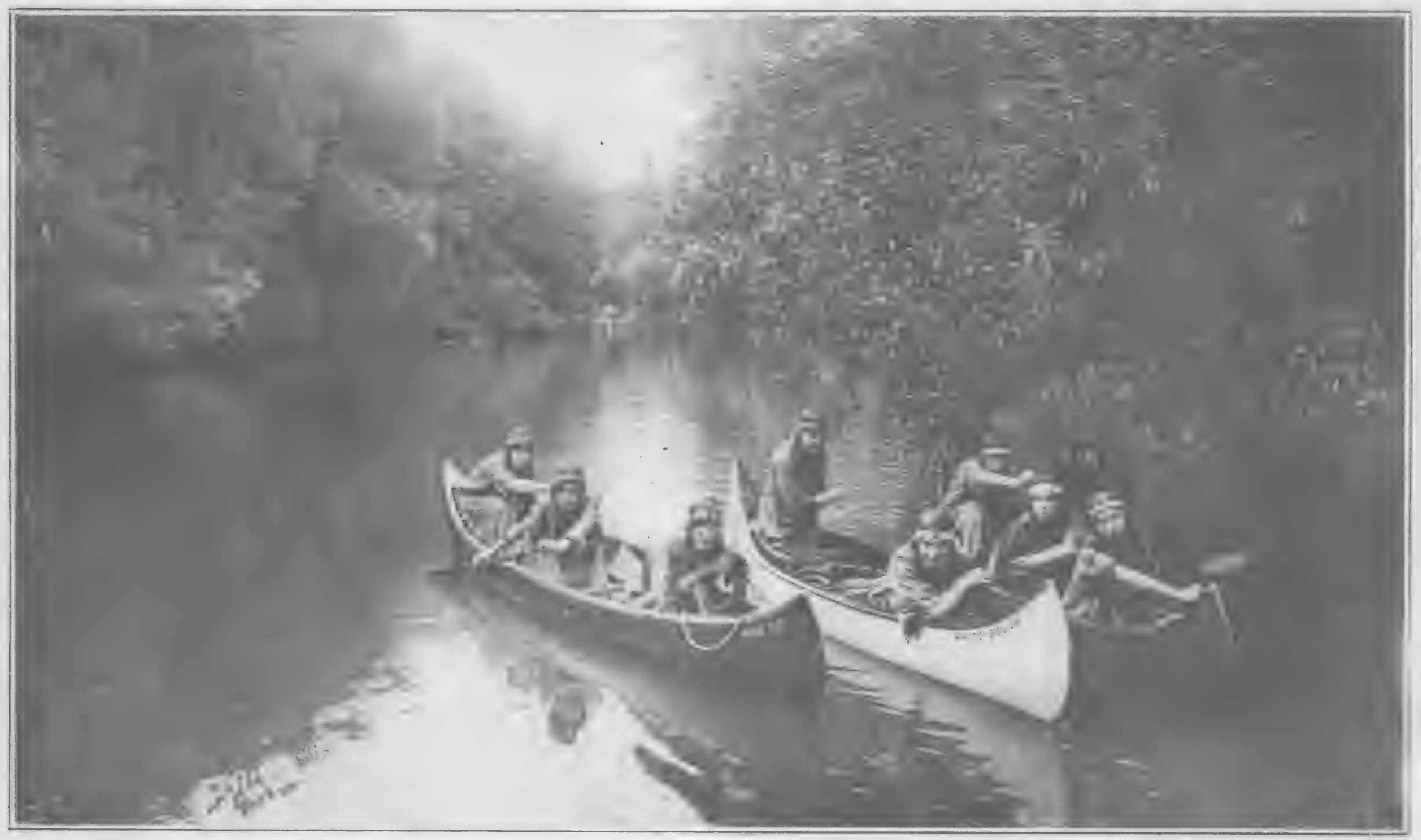




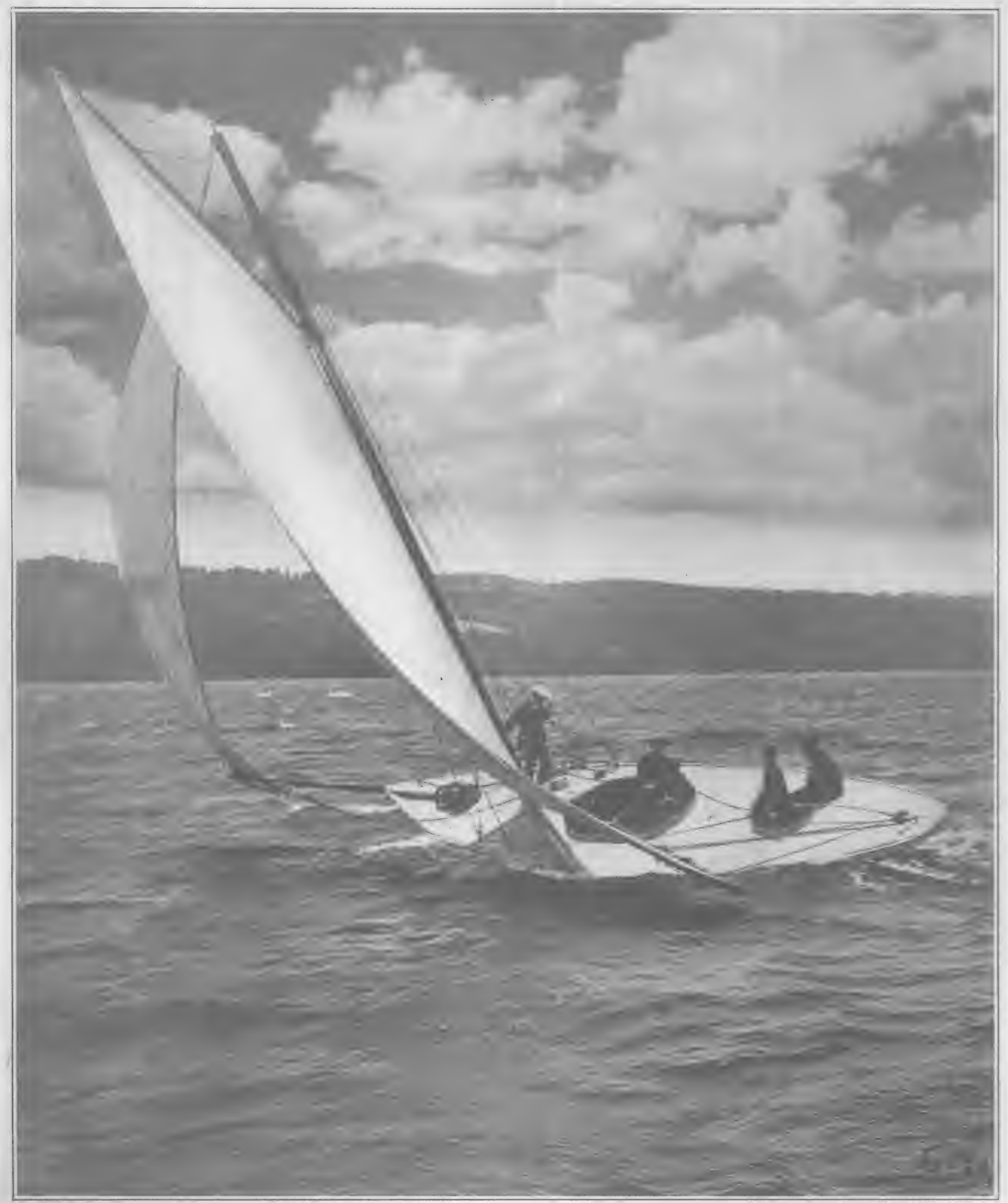




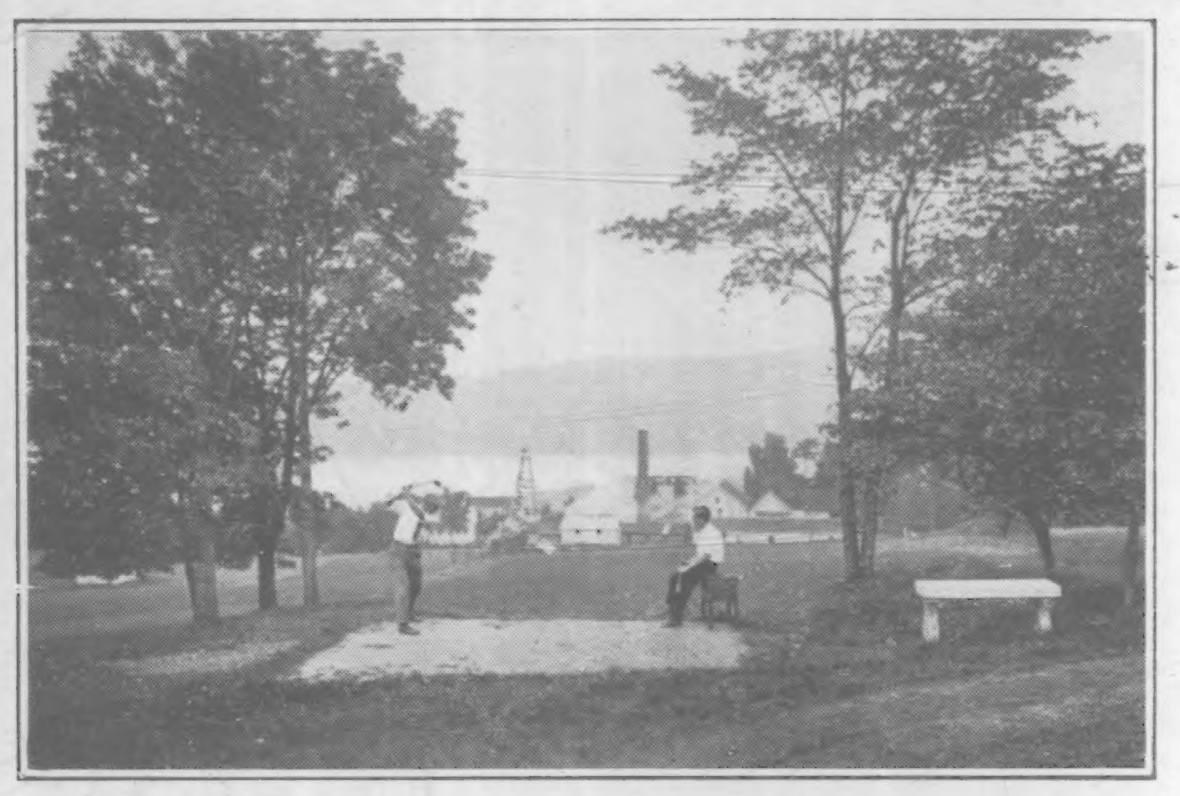

On the Links

village is noted for the progressive spirit of its citizens. Every street in the village has been paved with brick or macadam.

Cayuga Lake has two resort hotels which have been continued from year to year in spite of the fact that the Finger Lakes Region has been almost forgotten during recent years. Sheldrake near Interlaken and Glenwood, midway between Ithaca and Trumansburg are ideal spots in which to spend a vacation.

\section{Seneca Falls}

Seneca Falls a village of 8,000 population is the site of one of the most important power developments in the state. The village is located on the Seneca River where it falls fifty feet within a mile. Until the construction of the New York State Barge Canal (I9I5) the power was developed at various plants. The construction of a large dam at the eastern boundary of the village wiped out the industrial section of the village and made it possible to develop 8,000 horse power at a central power station. The dam forms Van Cleef Lake known as the "million dollar lake" because of the sum of money expened by the state in the canalization of the Seneca River at this point. Boats are lowered and raised fifty feet from the level of Cayuga Lake - through twin locks.

\section{Sa-go-ye-wat-ha}

Canoga, the birthplace of the famous Indian chief and orator Sa-go-ye-wat-ha or Red Jacket, is only a few miles from Seneca Falls. A handsome monument has been erected in memory ot Red Jacket at Canoga. Red Jacket was of great assistance to General Washington and the other leaders of the nation in the early days in bringing about better feeling between the Iroquois and the new government. He was awarded a medal by Congress for his assistance.

\section{A Beautiful Drive}

One of the most beautiful drives in the Finger Lakes Region, but one not to be attempted except when the roads are dry, is from Seneca Falls to East Varick along the west shore of Cayuga Lake. The roadway for almost the entire distance is within a few hundred feet of the lake shore.

On the east shore of the lake, near its foot, is the little village of Cayuga, once an important station on the Albany to Buffalo stage line. A bridge, a mile in length, crossed Cayuga Lake at this point. Union Springs and Aurora, the home of Wells College and Wallccurt School, are other villages on the eastern shore. Near the head of the lake is a large quarry and cement plant and two large salt plants. Cottages dot the

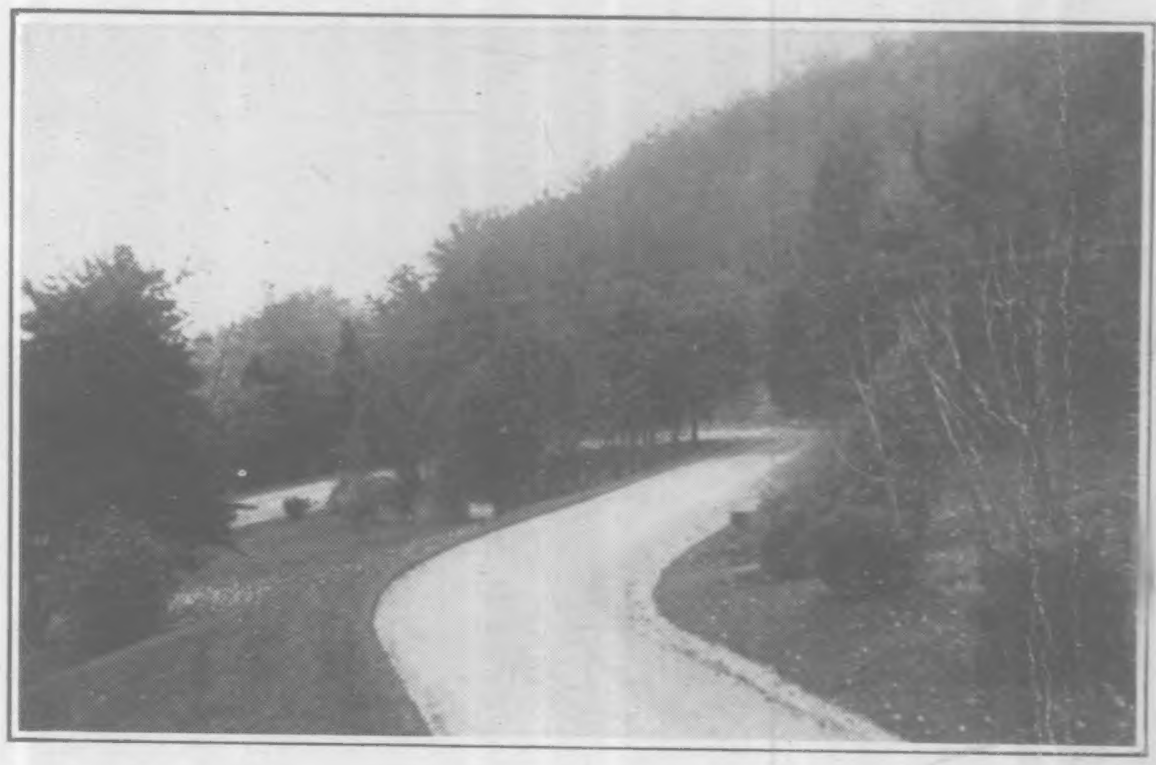

A Good Road 
points along both shores of Cayuga Lake. The largest colonies are near Cayuga and at Cayuga Lake Park, which is connected with Seneca Falls by an electric railroad.

\section{Owasco Lake}

Owasco Lake has particular attractions for the fisherman and for persons who enjoy swimming. Auburn, the largest city in the Finger Lakes Region is connected with the head of Owasco Lake by electric railways. Lakesicle Park is the most beautiful resort park in the whole region. It has beautiful grounds, a large pavilion for dancing, amusement features and bathing facilities. Owasco Lake is extremely picturesque. Its shores abound in glens and gorges of great. beauty.

Because of its accessibility by rail the west shore of Owasco Lake has many summer homes. 'The Lehigh Valley railroad runs within a short distance of the western shore of the lake for almost its entire length. Cottages may be rented by the week or the season.

\section{Auburn}

The Auburn Theological Seminary, a Presbyterian institution, and Auburn States Prison are located in Auburn. The city is well developed along industrial lines. Much of the improvement made in harvesting machinery during the last century was due to the inventive genius and ability of Auburnians. Its industries are varied in nature and large in extent.

Auburn is the birthplace of William H. Seward, Lincoln's Secretary of State. It is one of the most enterprising cities of New York State. The visitor who wishes to tour the Finger Lakes Region will do well to make Auburn his headquarters.

The Owasco River which runs through the center of the city gives opportunity for that splendid outdoor sport-canoeing. Various can- oe clubs have been organized for promoting the sport. Yachting and motor boating are other popular forms of outcloor exercise on Owasco Lake.

\section{Skaneateles Lake}

"The most beautiful lake in the worlo,", is the remark made by William H. Seward as he looked upon Skaneateles Lake after his trip around the world. Romanticists have given "The Beautiful Squaw" as the interpretation of the Indian name "Skan-e-at-les," but the more prosaic name of "Long Lake" seems to be better authorized.The village of Skaneateles at the foot of the lake is admirably located.

\section{The Origin of the \\ Finger Lakes}

Geologists have given much study to the Finger Lakes Region and detailed accounts both of a scientific and popular nature may be obtained by those interested in continuing the study. Professor O. D. VonEngeln in his recent book "Concerning Cornell" treats the subject of the geography of the region somewhat in detail.

In the most ancient geogolic time, according to Professor VonEngeln's book the Finger Lakes Region was the bottom of a shallow interior sea. At a later date it seems to have been a saline, desert basin. This accounts for the strata of salt found under the ground today.

Layers of clay, salt, sand and lime were laid down and some of the clay and sand layers were converted into shale and sandstones by the pressure of material deposited later. When the Appalachian Mountains were uplifted the Finger Lakes Region was carried along and a comparatively level highland was formed. A slight compression during the period of uplift formed low arches and troughs in the rocks. These in time became broad stream valleys. Another uplift seems to have followed.

$$
\text { Page twenty-three }
$$




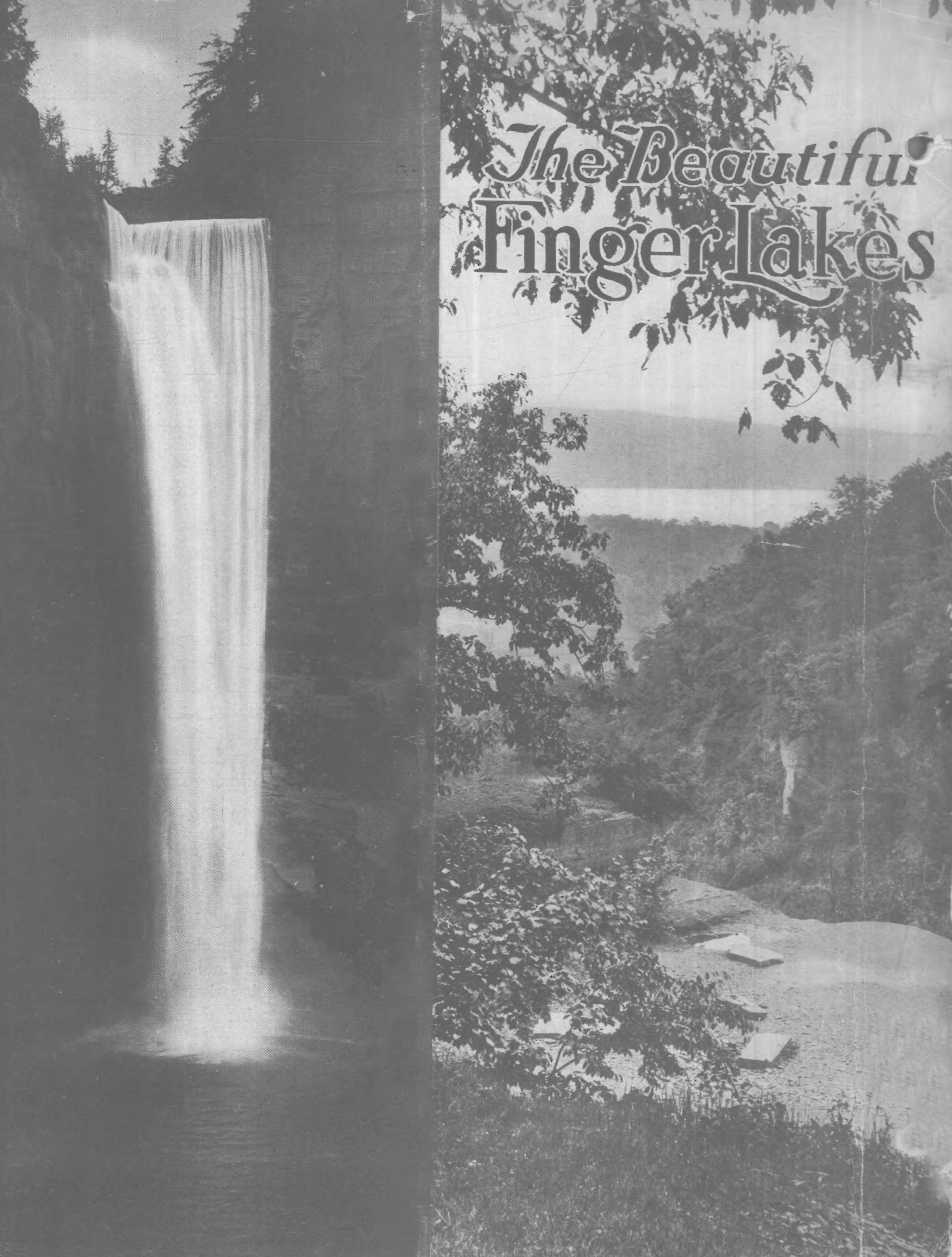


